\title{
Use of Advanced Borehole Geophysical Techniques to Delineate Fractured-Rock Ground-Water Flow and Fractures Along Water-Tunnel Facilities in Northern Queens County, New York
}

A dvanced borehole geophysical methods were used to assess the geohydrology of crystalline bedrock along the course of a new water tunnel for New York City. The logging methods include natural gamma, spontaneous potential, single-point resistance, mechanical and acoustic caliper, focused electromagnetic induction, electromagnetic resistivity, magnetic susceptibility, borehole-fluid temperature and conductance, differential temperature, heat-pulse flowmeter, acoustic televiewer, borehole deviation, optical televiewer, and borehole radar. Integrated interpretation of the geophysical logs from an 825-foot borehole (1) provided information on the extent, orientation, and structure (foliation and fractures) within the entire borehole, including intensely fractured intervals from which core recovery may be poor; (2) delineated transmissive fracture zones intersected by the borehole and provided estimates of their transmissivity and hydraulic head; and (3) enabled mapping of the location and orientation of structures at distances as much as $100 \mathrm{ft}$ from the borehole.

Analyses of the borehole-wall image and the geophysical logs from the borehole on Crescent Street, in northern Queens County, are presented here to illustrate the application of the methods. The borehole penetrates gneiss and other crystalline bedrock that has predominantly southeastward dipping foliation and nearly horizontal and southeastward-dipping fractures. The heat-pulse flowmeter logs obtained under pumping and nonpumping conditions, together with the other geophysical logs, indicate five transmissive fracture zones. More than 90 percent of the open-hole transmissivity is associated with a fracture zone

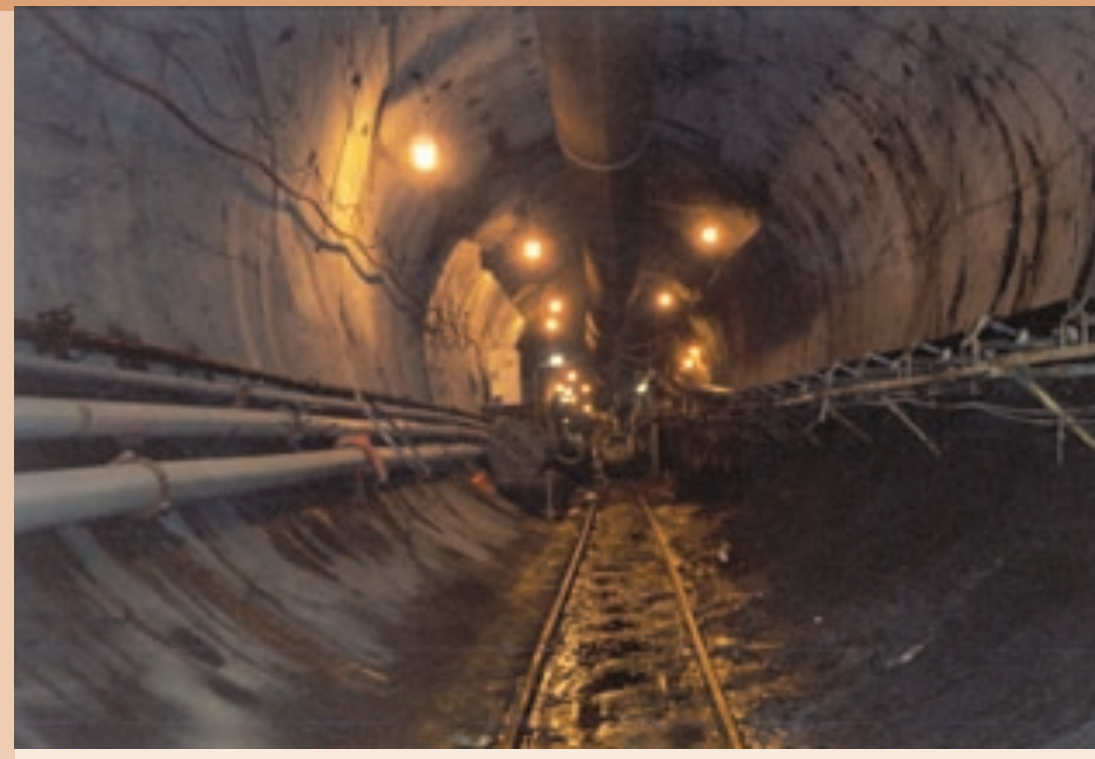

272 feet BLS (below land surface). A transmissive zone at 787 feet BLS that consists of nearly parallel fractures lies within the projected tunnel path; here the hydraulic head is 12 to 15 feet lower than that of transmissive zones above the 315 -foot depth. The 60-megahertz directional borehole radar logs indicate the location and orientation of two closely spaced radar reflectors that would intersect the projection of the borehole below its drilled depth.

Subsequent excavation of the tunnel past the borehole allowed comparison of the log analysis with conditions observed in the tunnel. The tunnel was found to intersect gneiss with southeastward dipping foliation; many nearly horizontal fractures; and a southeastward dipping fracture zone whose location, character, and orientation was consistent with that of the mapped radar reflectors. The fracture zone produced inflow to the tunnel at a rate of 50 to 100 gallons per minute. All conditions indicated by the logging methods were consistent with those observed within the tunnel. 


\section{INTRODUCTION}

In 1970, the New York City Department of Environmental Protection (NYCDEP) began construction of a third tunnel to supply water to New York City in the event that one of the two existing tunnels should require repair. Test borings were drilled to identify the type of rock and its degree of fracturing at the proposed tunnel depths, but the cores were not oriented, and the coring process can cause new fractures and can alter the extent of existing fractures. Furthermore, neither the hydraulic characteristics of the fractures, nor the vertical deviation of the boreholes, were known.

In 1998, the U.S. Geological Survey (USGS), in cooperation with the NYCDEP, began a study to demonstrate the use of advanced borehole geophysical methods to provide a more comprehensive geologic and hydrologic assessment of the crystalline bedrock along the proposed tunnel routes. These techniques were used in the available boreholes to identify the bedrock lithology and major contacts; the location and orientation (true strike and dip) of fractures and foliation of the rock intersected by the borehole, and the hydraulic characteristics of transmissive fracture zones. This report describes the use of these methods in a borehole on Crescent Street in northern Queens County (fig. 1) and summarizes the geophysical interpretations.

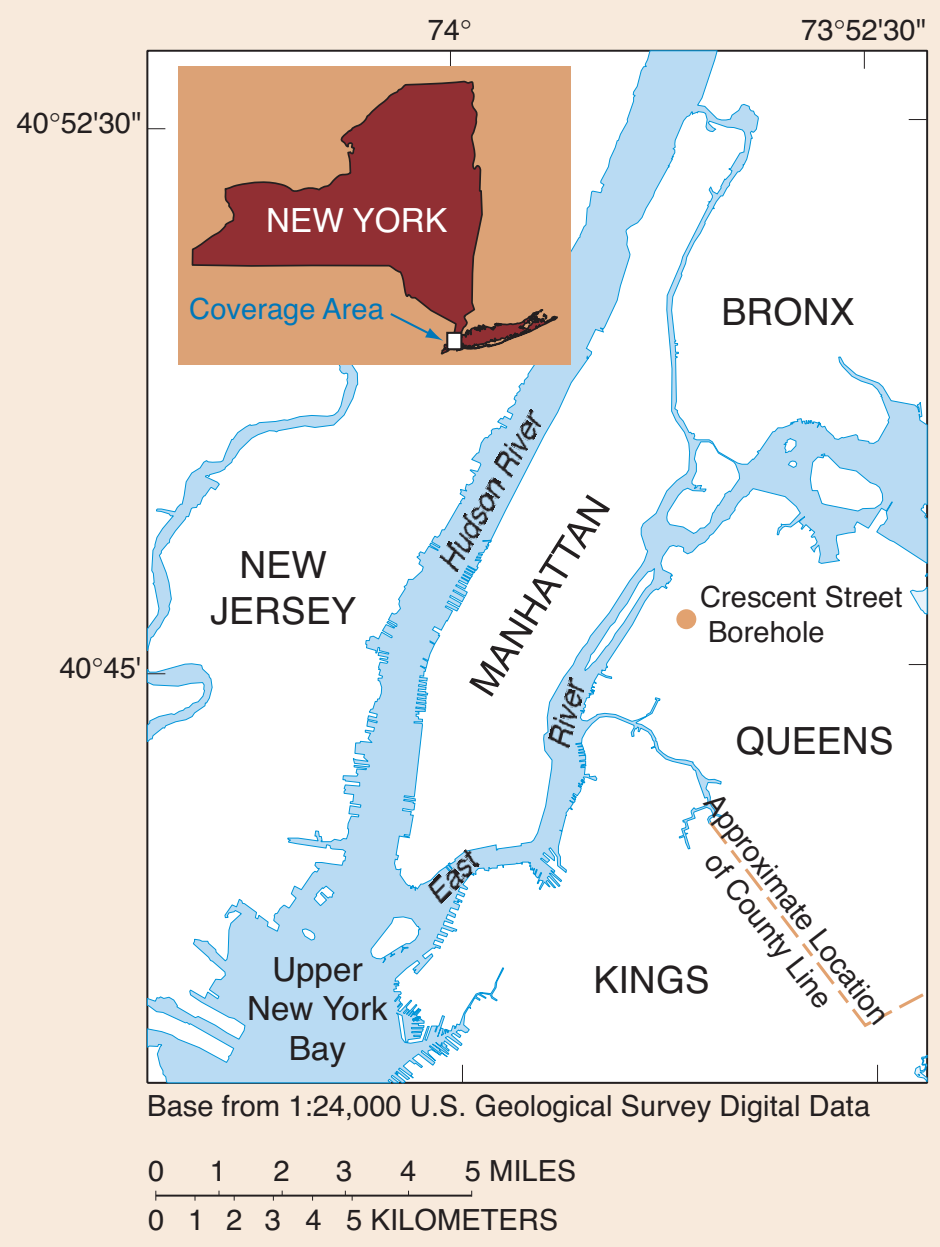

Figure 1. Location of the Crescent Street borehole, in northern Queens County, N.Y. 


\section{BOREHOLE-GEOPHYSICAL LOGGING METHODS AND APPLICATIONS}

Borehole-geophysical logs collected in this investigation included natural gamma, spontaneous potential, single-point resistance, mechanical and acoustic caliper, focused electromagnetic induction, magnetic susceptibility, borehole-fluid temperature and conductance, differential temperature, heat-pulse flowmeter, acoustic televiewer, borehole deviation, optical televiewer, and borehole radar. These logs and their applications are described briefly below.

- Natural-gamma (gamma) logs are a record of the total gamma radiation detected in a borehole (Keys, 1990) and are most commonly used for lithologic and stratigraphic correlation. Radioisotopes in bedrock minerals such as feldspar and mica are instrumental in correlating lithology. Clay minerals within fractures may be indicated by elevated gamma responses.

- Spontaneous-potential (SP) logs provide a record of the naturally occurring electrical potential difference along the borehole and can be used to identify changes in lithology, bed thickness, streaming potential due to water movement, and salinity of formation water under some geologic conditions (Keys, 1990).

- Single-point resistance (SPR) logs provide a measure of the electrical resistance of the rock or formation, and are used to obtain qualitative lithologic information with a depth resolution approximately equal to the borehole diameter.

- Caliper logs provide information on lithology and the location of major fractures. Mechanical calipers use springloaded arms to profile the surface of the borehole wall. Acoustic calipers calculate the distance to the borehole wall from the travel time of the acoustic signal emitted from an acoustic televiewer (ATV) to provide high-resolution, compass-oriented logs (Keys, 1990).

- Focused electromagnetic induction (EM) logs provide a profile of formation electrical conductivity, from which ground water conductivity in situ can be inferred, with respect to depth. This technique uses an electromagnetic emitter coil to induce electrical eddy currents within a specified volume of the surrounding formation to generate a secondary electromagnetic field. The intensity of the secondary field received by the receiver coil is proportional to the formation's conductivity (Keys, 1990; Serra, 1984; Keys and MacCary, 1971).

- Magnetic-susceptibility (MAG) logs provide a record of the variations in magnetic minerals within the surrounding rock. Magnetite is the most common magnetic mineral, and local variations in its abundance may indicate lithologic contacts (McNeill and others, 1996). 
- Temperature logs measure the temperature of the fluid column as a function of depth and, if a temperature contrast is present, can provide information on the movement of ground water through the borehole and the location of areas that produce or accept water (Keys, 1990).

- Differential temperature logs depict the rate of change in temperature relative to depth, and help to indicate the location of areas of contrasting temperatures that are sometimes the result of inflow or outflow.

- Borehole fluid conductance logs of water in a borehole provide a record of the fluid's electrical conductance to provide an indication of salinity, and may also be useful to indicate zones of inflow or outflow if fluid conductivity contrasts are present.

- Heat-pulse flowmeter logs measure vertical flow in boreholes using a thermal tracer, and can indicate which fractures are producing or accepting water in a borehole under pumping and nonpumping conditions (Keys, 1990).

- Acoustic televiewer (ATV) uses a rotating transducer that transmits and receives high-frequency acoustic pulses to produce an image of the intensity of acoustic energy reflection and travel time. The ATV provides high-resolution information on the location and strike and dip of fractures within a borehole (Keys, 1990). The travel time of the acoustic signal is used to calculate distance to the borehole wall to provide an acoustic caliper log.

- Borehole-deviation logs provide information on the borehole's angle and direction of deviation from vertical. Most boreholes deviate from vertical; therefore, deviation logs must be obtained before three-dimensional information on fractures is interpreted (Keys, 1990). After processing, the resulting log indicates the true depth of the borehole, its distance from vertical, and the direction or azimuth of deviation.

- Optical televiewer (OTV) digitally records a high-resolution optical scan of the borehole wall that can be used to produce a "virtual" core. The virtual core is oriented to allow for visualization of major fractures as they were imaged within the borehole. Fractures, both opened and sealed, can be viewed in three-dimensional orientations. This system also allows measurement of true strike-and-dip orientation and fracture spacing.

- Borehole radar, a 60-MHz directional radar unit (transmitter/receiver) that can be used in a single-hole reflectionmode to detect fracture zones and other structural features at distances to as much as $100 \mathrm{ft}$ from the borehole in electrically resistive rocks. Directional radar logs can be used to calculate the orientation of features such as fractures or fracture zones. 


\section{DELINEATION OF FRACTURES, AND DIRECTIONS OF GROUND-WATER FLOW}

Fractures and foliation were delineated through the use of OTV, ATV, borehole radar, gamma, SP, SPR, and EM logs. Hydraulic characteristics of the bedrock were determined through the use of fluid-temperature, differential-temperature, fluid specificconductance, and heat-pulse flowmeter logs, in concert with waterlevel data.

\section{GEOLOGIC CHARACTERISTICS OF BEDROCK}

The Crescent Street borehole (fig. 1) was drilled to a depth of $825 \mathrm{ft}$ in February 1999 and cased with steel to a depth of $85 \mathrm{ft}$ below land surface (BLS). The borehole has since been grouted. Land surface at the borehole was $25.56 \mathrm{ft}$ above sea level. Depth to water at the borehole in February 1999 ranged from 17.36 to $17.68 \mathrm{ft}$ BLS. The borehole-deviation log indicated the borehole to have a true depth of $815.4 \mathrm{ft}$ BLS. The borehole bottom appears to be only $2.7 \mathrm{ft}$ (measured horizontally) off vertical at an azimuth $\mathrm{N} 65^{\circ} \mathrm{E}$.

The regional foliation of rocks within the study area dips southeastward and contains several major faults (Baskerville, 1992). The Crescent Street borehole intersects bedrock of the Hartland Formation, of Middle Ordovician to Lower Cambrian age. Analysis of OTV and other logs, including core analysis by NYCDEP (C.A. Baskerville, Central Connecticut State University, written commun., 1999) indicate that the bedrock consists of a sequence of gneiss and schist interlayered with amphibolite, granite, and mylonite.

The ATV, borehole radar, and OTV data indicate that the rock penetrated by the borehole is moderately fractured and contains several distinct zones of highly fractured rock (fig. 2). Five distinct fracture zones were delineated from the geophysical logs. The OTV data indicated a total of 232 fractures between 85 and $825 \mathrm{ft}$ BLS. The ATV detected 84 of the 232 fractures delineated with the OTV. Plotting these data on an equal-area net as poles to planes (fig. 3) indicated two large fracture-population clusters - a major one and a minor one. The major cluster appears to be nearly horizontal, with a mean orientation of $\mathrm{N} 42^{\circ} \mathrm{E} 16^{\circ} \mathrm{NW}$ (fig. 3); the minor cluster has a mean orientation of $\mathrm{N} 39^{\circ} \mathrm{E}$ (plane strike) $59^{\circ} \mathrm{SE}$ (plane dip) (fig. 3). When fracture data were plotted with respect to depth of transmissive fractures, no clear pattern was detected.

Analysis of the $60-\mathrm{MHz}$ directional radar data indicated two closely spaced strong radar reflectors that would intersect the borehole if it were drilled deeper (fig. 4). These are the strongest reflectors detected in this borehole and are interpreted as fractures that are infilled with either metallic minerals such as pyrite, or with water. Radar data indicate that these fractures extend more than $100 \mathrm{ft}$ from the borehole and have orientations of $\mathrm{N} 30^{\circ} \mathrm{E} 69^{\circ} \mathrm{SE}$ and $\mathrm{N} 40^{\circ} \mathrm{E} 66^{\circ} \mathrm{SE}$. This orientation indicates that these fractures, if water bearing, could pose a flooding hazard to equipment and personnel in the tunnel.

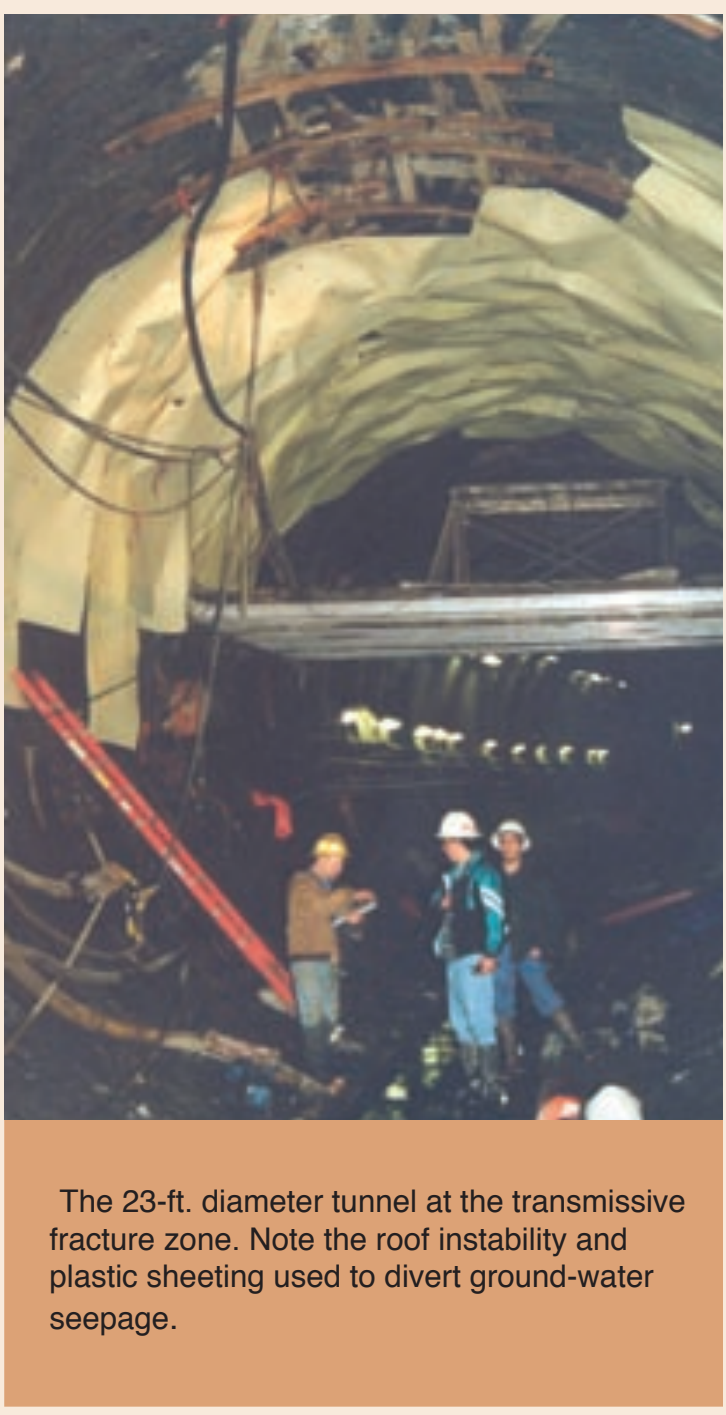

The OTV also detected the foliation of the metamorphic rocks penetrated by the borehole; 208 measurements of foliation were made and their orientations plotted (fig. 3). Two clusters of data points can be seen; the major cluster (165 data points) has an orientation of $\mathrm{N} 54^{\circ} \mathrm{E} 54^{\circ} \mathrm{SE}$ (fig. 3); the minor cluster has an orientation of $\mathrm{N} 42^{\circ} \mathrm{E} 62^{\circ} \mathrm{NW}$. Vertical variation in foliation and orientation is shown in tadpole plots (fig. 5).

The foliation and fracture data at depths of 700 to $825 \mathrm{ft}$ BLS were plotted on a stereo net (not shown). The foliation data ( 55 data points) produced a single cluster with a mean 


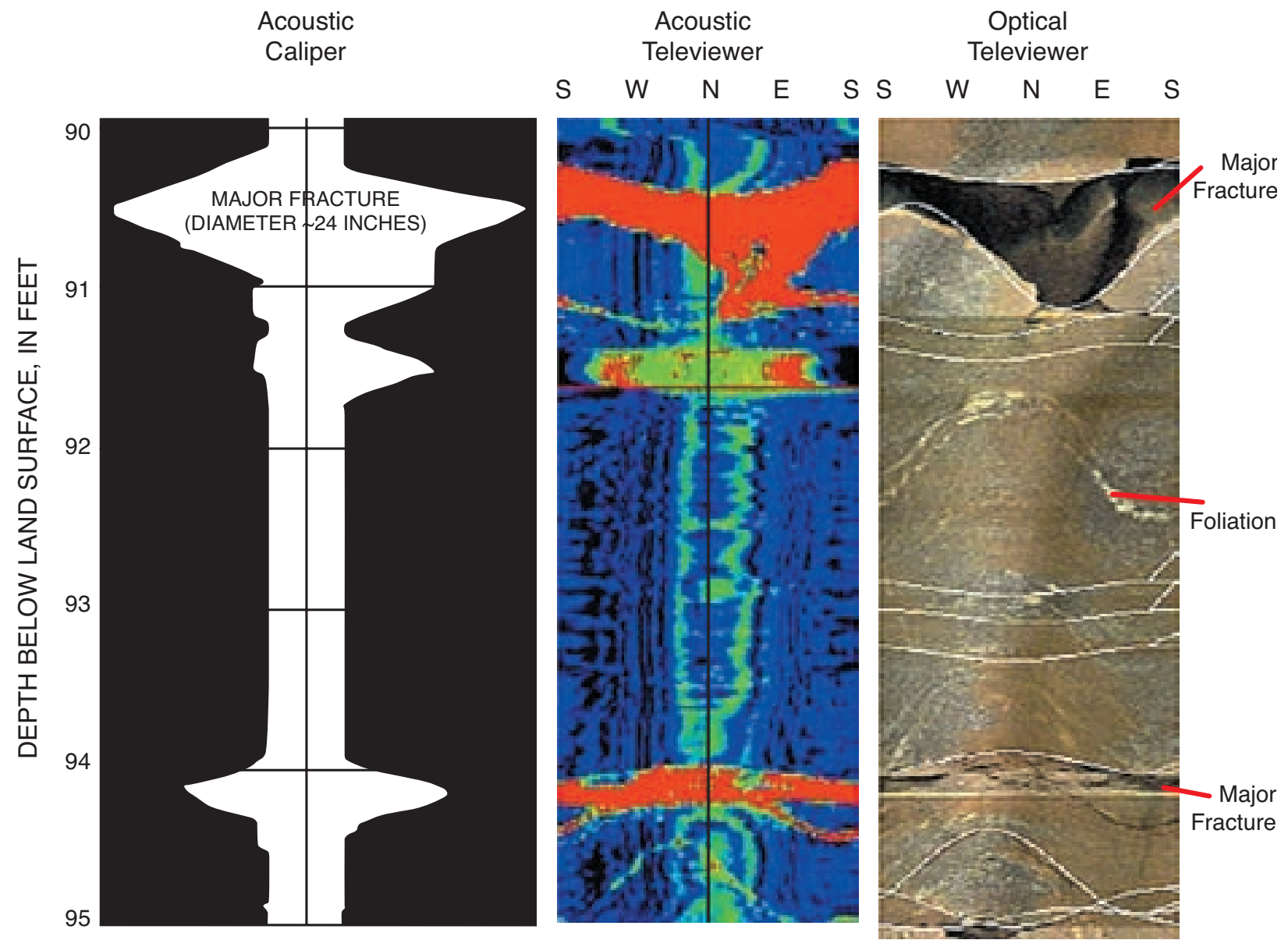

Figure 2. Acoustic caliper, acoustic televiewer, and optical televiewer images of fractures in the Crescent Street borehole, in northern Queens County, N.Y.

strike and dip of $\mathrm{N} 45^{\circ} \mathrm{E} 60^{\circ} \mathrm{SE}$. A total of 43 fracture-data points produced one major population cluster and several minor surrounding clusters. The majority of fractures have a mean strike and dip of $\mathrm{N} 84^{\circ} \mathrm{W} 5^{\circ} \mathrm{SW}$ and are nearly horizontal.

The gamma log indicates some variation in clay and mica-mineral content of the rock penetrated by the borehole (fig. 5). Three distinct changes in the gamma logs were indicated - at depths of 169 , from 471 to 485 , and from 495 to $500 \mathrm{ft} \mathrm{BLS}$, and corresponded with observations in the OTV log. An increase in gamma radiation at $169 \mathrm{ft}$ BLS corresponds to clay minerals within a transmissive fracture. A decrease in gamma radiation in the zone from 471 to $485 \mathrm{ft}$ corresponds to a thick sequence of amphibolite. Just below this zone, from 495 to $500 \mathrm{ft}$, an increase in gamma radiation may correspond to clay minerals within a fracture at this depth. In general, the gamma log of this borehole is fairly uniform and shows only minor variations. The spontaneous potential (SP) log shows several peaks or increases in voltage (possibly from streaming potentials) that correspond to fractures at 91, 95, 169, 272, and $384 \mathrm{ft}$, and from 495 to $500 \mathrm{ft}$ BLS (fig. 5).

When compared with the OTV data, the SPR log (fig. 5) indicates detailed variations that correspond to changes in rock mineralogy and conductive material (clay or pyrite minerals) within fracture zones. The electrical resistance of the rock shows a greater variability above about $500 \mathrm{ft}$ BLS than below this depth (fig. 5), and the magnetic-susceptibility log indicates a corresponding increase in magnetite above about $500 \mathrm{ft}$; in contrast, the area below this depth indicates almost no variation in magnetic susceptibility. The SPR log indicates decreases in resistance at 91, 95, 169, 272, 384, 500, and $787 \mathrm{ft}$ BLS. These decreases correspond to significant clay or mineralized 

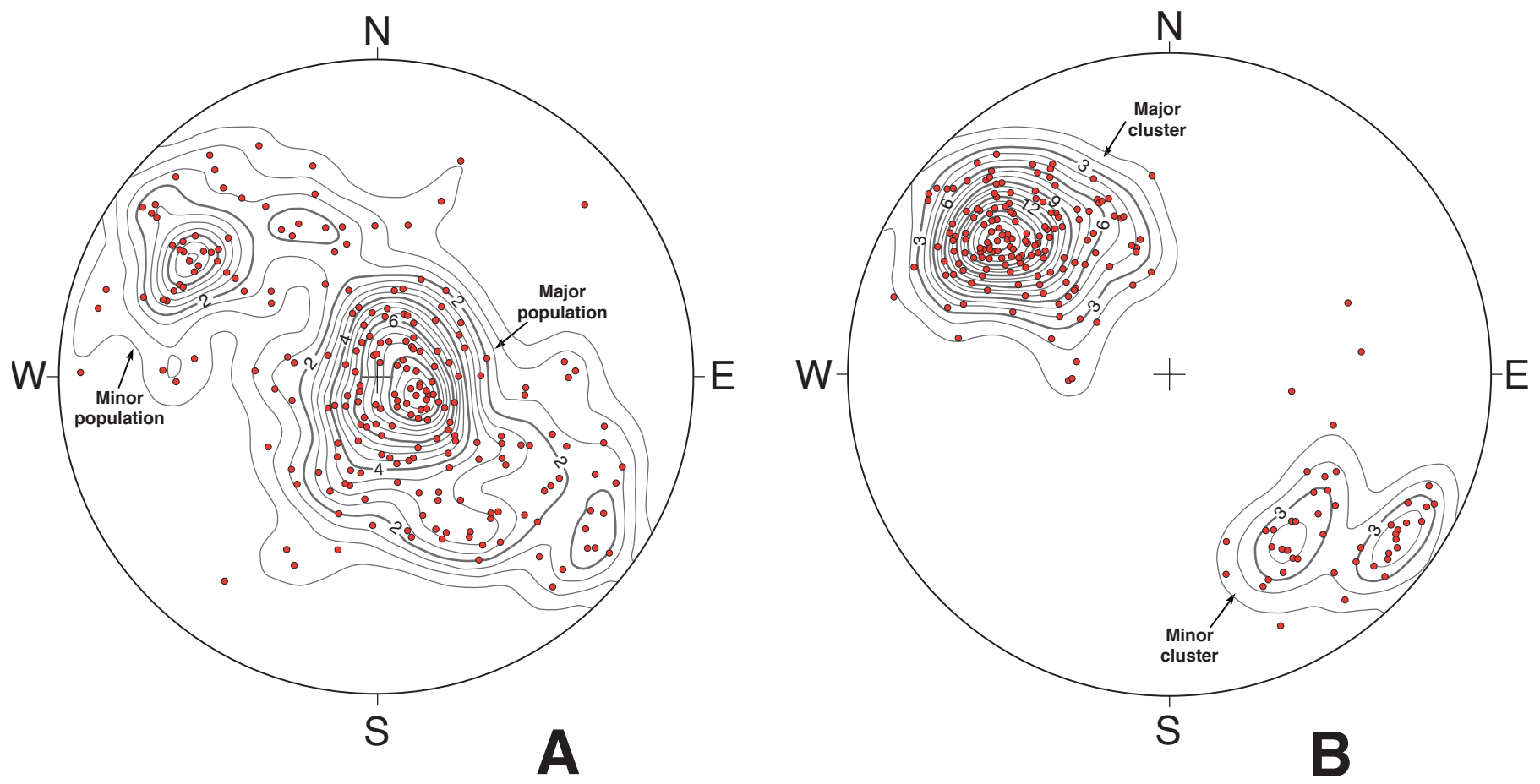

A Number of fractures: 232

B Number of foliations: 208

Figure 3. Equal-area net of $\mathrm{A}$. fractures, and B. foliation from 85 to $825 \mathrm{ft}$ below land surface from optical televiewer analysis of the Crescent Street borehole, in northern Queens County, N.Y.

fracture zones. Similar increases in electrical conductivity or decreases in resistivity are indicated in the EM-conductivity $\log$ (fig. 5). Conductivity increases gradually to a depth of $272 \mathrm{ft}$ BLS, below which it then gradually decreases with depth; this reversal suggests a change in rock composition.

Tadpole plots of the fractures and foliation measured from the ATV and OTV logs indicate variations in the dip angle and dip azimuth of these fractures with depth. Foliation has dip angles from 30 to $80^{\circ}$ toward the southeast. In general, foliation dip angles increase from 60 to $80^{\circ}$ to the southeast at the tunnel depth. The tadpole plot of fractures indicate that the bedrock is moderately fractured with several zones that are highly fractured. The upper $500 \mathrm{ft}$ of bedrock has a significantly higher density of fractures than the rock below this depth. The dip azimuth and dip angle of fractures had no general pattern, with fracture dip angles ranging from sub-horizontal to nearly vertical.

\section{HYDRAULIC CHARACTERISTICS OF BEDROCK}

Ground-water flow may cause erratic and abnormal temperature gradients near land surface; thus, temperature logs may indicate a decrease in temperature with depth - the inverse of the normal geothermal gradient (Keys, 1990; Williams and Conger, 1990). The fluid-temperature and differential-temperature logs of the borehole indicate several changes in water temperature under non-pumped (ambient) conditions (fig. 6). The fluid-temperature log indicates watertemperature changes at 91 to $95 \mathrm{ft}$, at $272 \mathrm{ft}$, at $315 \mathrm{ft}$, and at $787 \mathrm{ft} \mathrm{BLS}$. As discussed further on, these changes correspond to fractures that either accept water from, or yield water to the borehole. The fluid specific conductance log indicates changes at 91 to $95 \mathrm{ft}$, at $169 \mathrm{ft}$, at $272 \mathrm{ft}$, and from 315 to $321 \mathrm{ft} \mathrm{BLS}$ under 


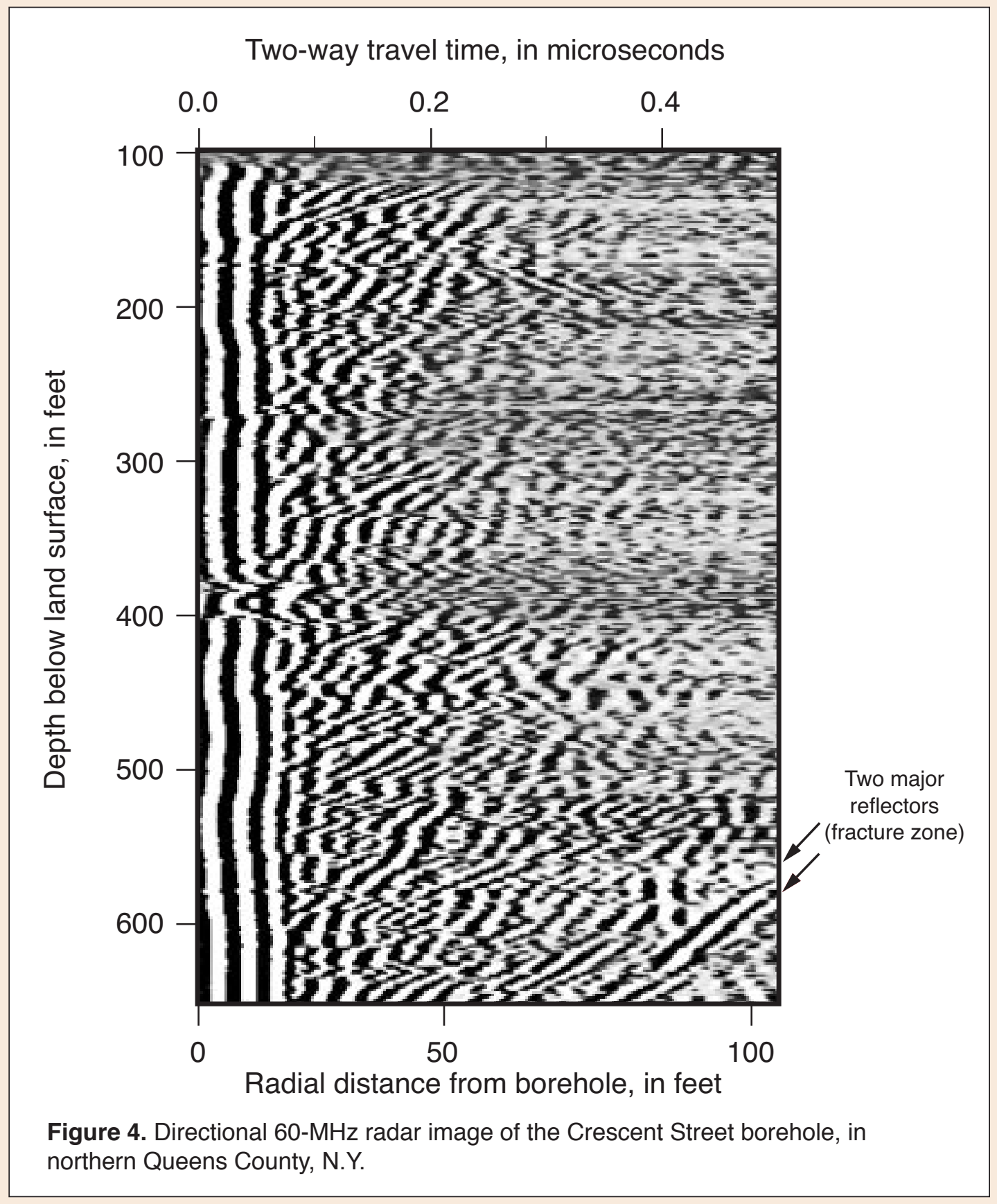

ambient conditions. Specific conductance ranged from about $700 \mu \mathrm{S} / \mathrm{cm}$ (microsiemens per centimeter) near the water surface at $90 \mathrm{ft} \mathrm{BLS}$ to about $580 \mu \mathrm{S} / \mathrm{cm}$ at the bottom of the hole (fig. 6). Sudden shifts in the water-temperature log or the specific-conductance log are indicative of ground water entering or leaving the borehole through fractures.

Ground-water temperatures were highest $\left(62^{\circ} \mathrm{F}\right)$ at the water surface and decreased with depth to about $53^{\circ} \mathrm{F}$ at the 500-ft depth (fig. 6). Temperature decreased from about $58^{\circ} \mathrm{F}$ to about $55^{\circ} \mathrm{F}$ between 90 and $272 \mathrm{ft} \mathrm{BLS}$, and a significant temperature change from $55^{\circ} \mathrm{F}$ to $54^{\circ} \mathrm{F}$ was recorded at $272 \mathrm{ft}$ BLS. These temperature changes are probably due to ground-water inflow from several fracture zones. Below $500 \mathrm{ft}$, the water temperature increased gradually with depth, except at about $787 \mathrm{ft}$, where it abruptly increased from about $54^{\circ} \mathrm{F}$ to about $55^{\circ} \mathrm{F}$ (fig. 6). The differential temperature log indicates a variation in fluid temperature with depth as rapid departures from a vertical line.

Ground-water levels were measured during pumping and nonpumping conditions, and heat-pulse flowmeter logs were obtained to quantify hydraulically transmissive fractures at discrete depths within the borehole during 


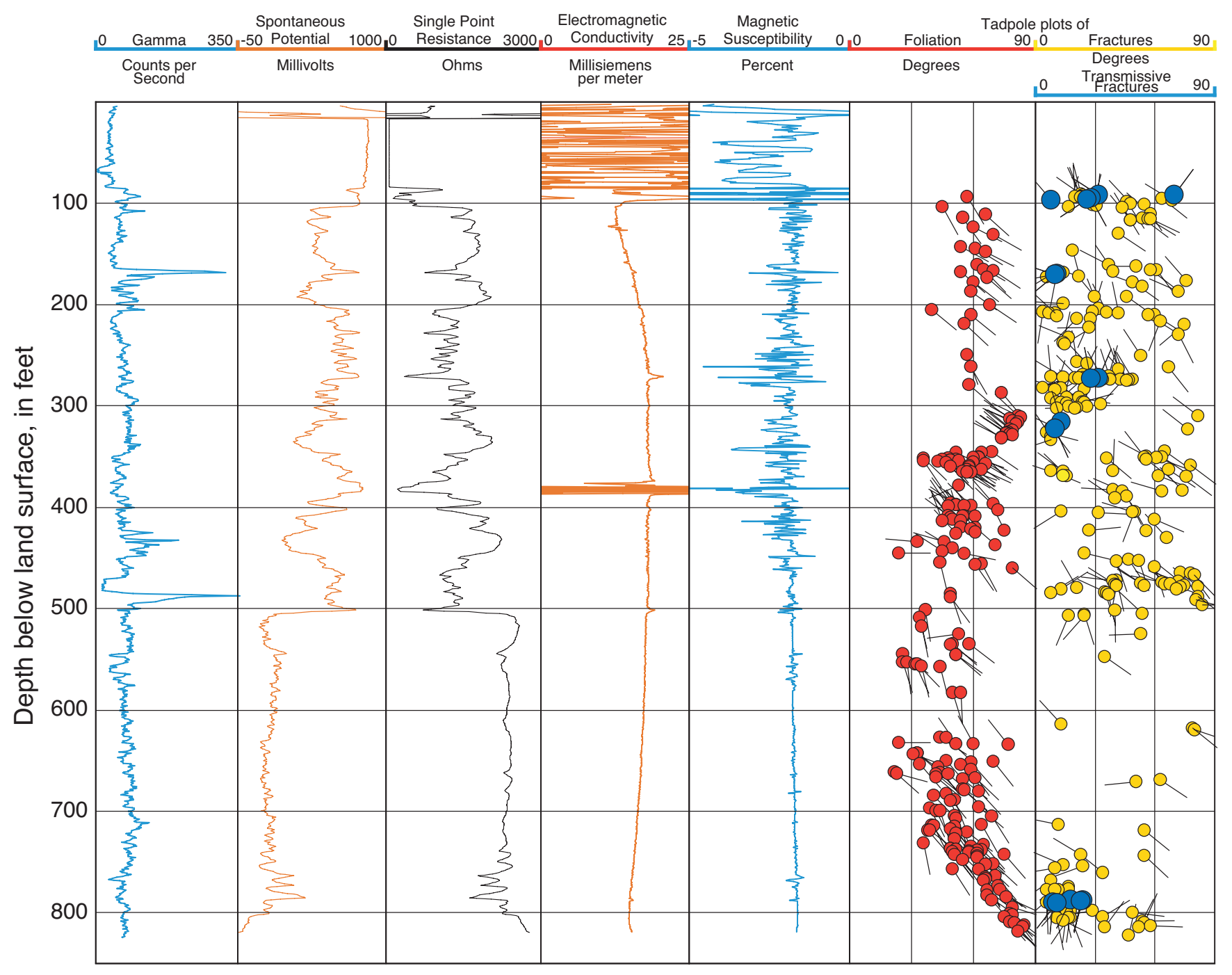

Figure 5. Suite of geophysical logs used to interpret geologic characteristics at the Crescent Street borehole, in northern Queens County, N.Y.

pumping and nonpumping conditions (fig. 6). A submersible pump was used to lower the head in the borehole. The major hydraulically transmissive fracture zones were delineated, from several types of logs, at depths of 91 to $95 \mathrm{ft}, 169 \mathrm{ft}, 272 \mathrm{ft}, 315$ to $321 \mathrm{ft}$, and $787 \mathrm{ft}$ BLS.

Water levels, pumping rate, and the temperature and specific conductance of the pumped water were monitored during the heat-pulse flowmeter logging. The change in water levels over the duration of pumping was used to calculate the specific capacity of the open borehole. The water level decreased $3.57 \mathrm{ft}$ over a 2.95 -hour period of pumping at an average rate of $4.5 \mathrm{gal} / \mathrm{min}$. The specific capacity for the entire borehole, based on these values, was $1.26(\mathrm{gal} / \mathrm{min}) / \mathrm{ft}$. The specific capacity data were analyzed with a program developed by Bradbury and Rothschild (1985) that estimated the range in transmissivity for the entire borehole to be $350 \mathrm{ft}^{2} / \mathrm{d}$ to $420 \mathrm{ft}^{2} / \mathrm{d}$.

The heat-pulse flowmeter log indicates that (1) all significant flow into the borehole is occurring above the 289-ft depth (fig. 6), and (2) fractures within the tunnel depth (764 to $787 \mathrm{ft}$ BLS) are accepting water from the borehole at a rate of about $0.25 \mathrm{gal} / \mathrm{min}$ under ambient conditions. The heat-pulse flowmeter 


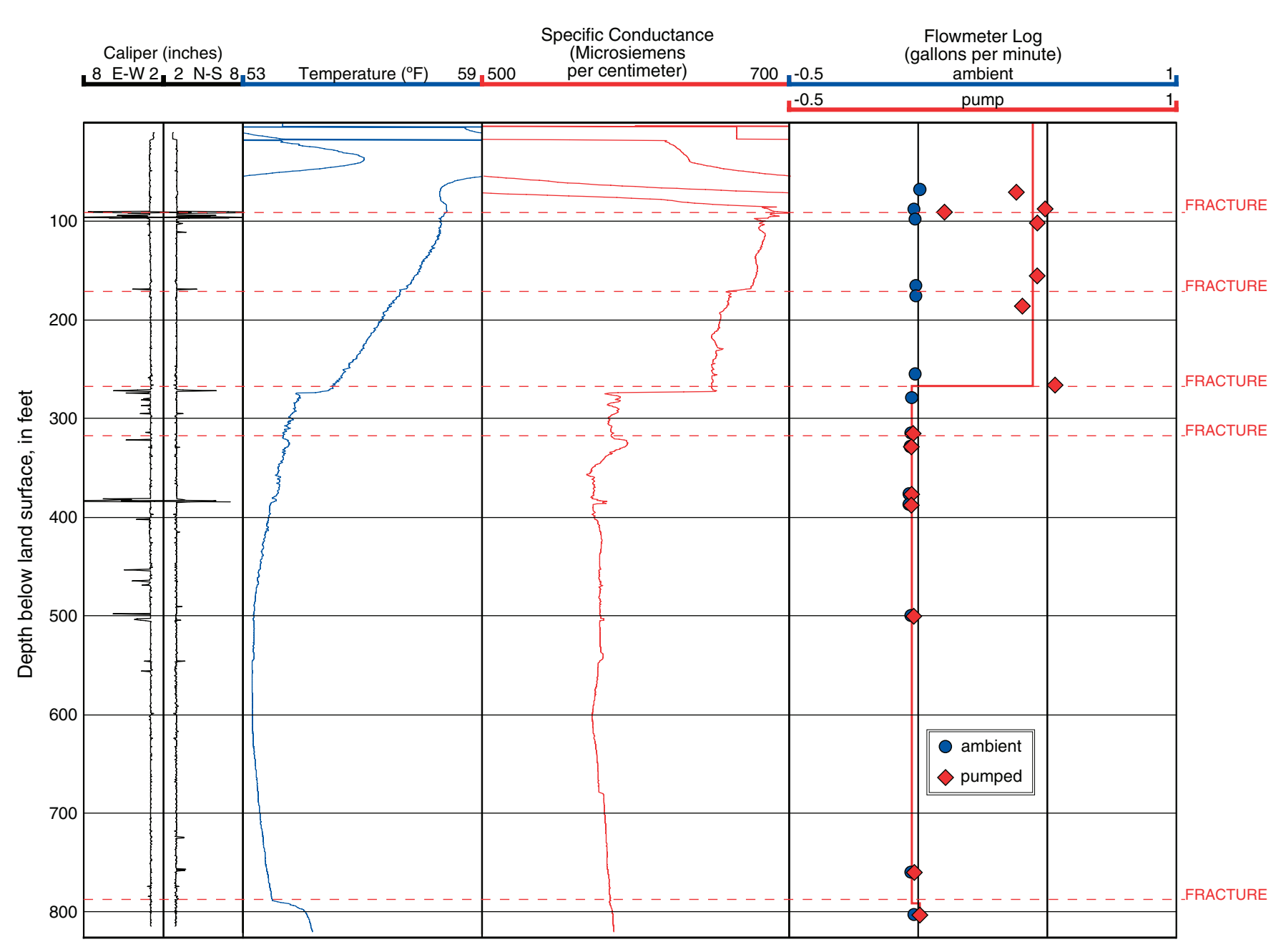

Figure 6. Suite of geophysical logs used to interpret hydraulic characteristics of bedrock at the Crescent Street borehole, in northern Queens County, N.Y.

data indicate a slight downward flow component under ambient conditions from below the casing to $787 \mathrm{ft}$ BLS (fig. 6). Measurable changes in flow were noted in the transmissive zones at $272 \mathrm{ft}$ and at 787 to $790 \mathrm{ft}$. The increase in downward flow from 255 to $279 \mathrm{ft}$ indicates that one or more of the fractures at $272 \mathrm{ft}$ are contributing water to the borehole. The decrease in downward flow from 88 to $98 \mathrm{ft}$ and from 760 to $802 \mathrm{ft}$ indicates that fractures at 91 and $95 \mathrm{ft}$ and at 787 to $790 \mathrm{ft}$ were accepting water under ambient conditions. Downward flow was noted below about $92 \mathrm{ft}$, with a small increase between 272 and $316 \mathrm{ft}$; all flow exited at about $787 \mathrm{ft}$ (fig. 6).

Under pumping conditions, the heat-pulse flowmeter detected upward flow from 68 to $265 \mathrm{ft}$ BLS and at $802 \mathrm{ft}$ BLS (fig. 6). Downward flow was detected from
315 to $760 \mathrm{ft}$. The reversal from upflow to downflow between 265 and $315 \mathrm{ft}$ BLS suggests that water is entering the borehole from the fracture zone at $272 \mathrm{ft}$ BLS. In contrast, the fracture zone at 787 to $790 \mathrm{ft}$ BLS shows a reversal from downflow to upflow, indicating that the 787 to $790 \mathrm{ft}$ BLS zone is taking water from the borehole (fig. 6). A nominal weak, upward flow response below $800 \mathrm{ft}$ BLS is attributed to the buoyancy effect of a thermal tracer on the flowmeter response (Hess, 1986) and is interpreted as no measurable flow.

The flowmeter logs were analyzed through the techniques of Paillet (1998; 2000), whereby differences between flow values at adjacent stations are attributed to measurement scatter and a possible net difference in borehole flow. Therefore, flow-log interpretation involves identification of the relative amounts of inflow 
or outflow occurring at specific depth intervals. Inflow or outflow was interpreted at four different depth intervals, each of which coincides with a fracture, or sets of fractures. The effects of hydraulic-head differences between zones can be eliminated by subtracting the inflows under nonpumping conditions from the inflow under pumping conditions, where outflow is given as negative inflow, in accordance with the technique of Molz and others (1989). The result of the subtraction of inflows indicates that almost all of the transmissivity is associated with the fracture zone at $272 \mathrm{ft}$ BLS.

An alternative approach is to use a flow-modeling technique described by Paillet (2000), which involves inverting the two flow profiles and the measured drawdown under pumping conditions to give quantitative estimates of the transmissivity and relative hydraulic head of each transmissive zone. The results of this method indicate a 12- to 15-ft hydraulic-head difference between the fracture zones at $315 \mathrm{ft}$ BLS and above, and the fracture zone at $787 \mathrm{ft}$ BLS.

The ambient flow is weak because the outlet fracture zone at $787 \mathrm{ft}$ BLS has relatively low transmissivity. Pumping failed to reverse the ambient flow completely because the fracture zone at $272 \mathrm{ft}$ is relatively transmissive, so that open-borehole drawdown is only a fraction of the hydraulic-head difference between the various fractures.

\section{GEOLOGIC AND HYDRAULIC CONDITIONS OBSERVED IN THE TUNNEL NEAR THE BOREHOLE}

After the completion of the geophysical logging and $\log$ analysis, the tunnel-boring machine excavated past the Crescent Street borehole. The 23-ft diameter tunnel penetrated gneiss with southeastward dipping foliation and many nearly horizontal fractures. These fractures result in weak ceiling conditions in the tunnel-consistent with the prediction of a falling-rock hazard in that part of the tunnel identified from a plot of the mean orientations of the fractures and foliation delineated from the OTV log with respect to the tunnel. The tunnel also intersected a transmissive fracture zone whose location, character, and orientation were consistent with those of the mapped radar reflectors. The fracture zone, which contained some pyrite infillings, produced 50 to $100 \mathrm{gal} / \mathrm{min}$ of inflow to the tunnel.

\section{SUMMARY AND CONCLUSIONS}

The Crescent Street borehole was drilled along the course of a new water tunnel through northern Queens County to provide cores and a site for the collection of geophysical logs. The geophysical logs provided data on the deviation of the borehole from vertical, the location and orientation (strike and dip) of fractures, the orientation of rock foliation, locations of contacts between rock units of differing types, and locations of water-producing fractures; they also provided information on the rocks' magnetic susceptibility, electrical resistivity and resistance, spontaneous potential; the direction and quantity of ground-water flow, specific conductance and temperature of ground water, a profile of the borehole diameter, and the identification and orientation of significant fractures beyond the borehole.

The surrounding rocks are moderately fractured and contain several zones of extensive fracturing. The acoustic and optical televiewer data indicate a total of 232 fractures. Equal-area-net analysis of these fractures indicated the major cluster to have an orientation of $\mathrm{N} 42^{\circ} \mathrm{E} 16^{\circ} \mathrm{NW}$ and the minor cluster to have an orientation of $\mathrm{N} 39^{\circ} \mathrm{E} 59^{\circ} \mathrm{SE}$.

Analysis of the $60-\mathrm{MHz}$ directional radar indicates two closely spaced strong radar reflectors, which are probably fractures that extend beyond $100 \mathrm{ft}$ from the borehole and would intersect the borehole if it were deeper. Radar analysis indicates these fractures to have an orientation of $\mathrm{N} 30^{\circ} \mathrm{E} 69^{\circ} \mathrm{E}$ and $\mathrm{N} 40^{\circ} \mathrm{E} 66^{\circ} \mathrm{SE}$. This orientation indicates that these fractures, if water bearing, could pose a flooding hazard to equipment and personnel in the tunnel.

The foliation of rocks penetrated by the borehole was grouped into two large population clusters. The major cluster had a mean orientation of $\mathrm{N} 54^{\circ} \mathrm{E} 54^{\circ} \mathrm{SW}$, and the minor cluster had a mean orientation of $\mathrm{N} 42^{\circ} \mathrm{E} 62^{\circ} \mathrm{NW}$. Plotting the mean orientations of the fractures and foliation at the depth of the tunnel in three dimensions with respect to the tunnel indicates a potential for a falling-rock hazard in the tunnel. In addition, the large number of nearly horizontal fractures at this depth suggest a potential for rock weakness at the tunnel ceiling.

The gamma, SP, SPR, EM, conductivity, resistivity, fluidtemperature, differential temperature, and specific conductance logs all detected some of the fracture zones. The magneticsusceptibility log indicated changes in magnetite content of the rock within the borehole.

Five transmissive fracture zones were delineated by correlating inflow zones interpreted from heat-pulse flowmeter logs with major fracture zones indicated by other geophysical logs. Modeling of the flow-log response indicates that more than 90 percent of the open-hole transmissivity is associated with the fracture zone at $272 \mathrm{ft} \mathrm{BLS}$. These results indicate a 12- to 15 -ft hydraulic head difference at the time of logging 
(February 1999) between the fracture zones at $315 \mathrm{ft}$ and higher and the fracture zone at $787 \mathrm{ft}$-the depth of the projected tunnel interval.

The geophysical logging of the boreholes provided a unique opportunity for comparison of the cores with the geohydrologic conditions along the tunnel's course. The geohydrologic conditions encountered during subsequent excavation of the tunnel near the borehole were consistent with those interpreted from the geophysical logs.

\section{REFERENCES CITED}

Baskerville, C.A., 1992, Bedrock and engineering geologic maps of Bronx County and parts of New York and Queens Counties, New York: U.S. Geological Survey Miscellaneous Investigations Series, map I-2003, 2 sheets, scale 1:24,000.

Bradbury, K.R., and Rothschild, E.R., 1985, A computerized technique for estimating the hydraulic conductivity of aquifers from specific-capacity data; Groundwater, v. 23, no. 2, p. 240-246.

Hess, A.E., 1986, Identifying hydraulically conductive fractures with a slow-velocity borehole flowmeter: Canadian Geotechnical Journal, v. 23, no. 1, p. 69-78.

Keys, W.S., and MacCary, L.M., 1971, Application of borehole geophysics to water-resources investigations: U.S. Geological Survey Techniques of Water Resources Investigations, book 2, chap. E1, 126 .

Keys, W.S., 1990, Borehole geophysics applied to water-resources investigations: U.S. Geological Survey Techniques of Water Resources Investigations, book 2 , chap. E2, $150 \mathrm{p}$.

Molz, F.J., Morin, R.H., Hess, A.E., Melville, J.G., and Guven, Oktay, 1989, The impeller meter for measuring aquifer permeability variations - evaluation and comparison with other tests: Water Resources Research, v. 25, no. 7, p. 1677-1683.

McNeill, J.D, Hunter, J.A., and Bosner, M., 1996, Application of a borehole induction magnetic susceptibility logger to shallow lithological mapping: Journal of Environmental and Engineering Geophysics, v. 0 , no. 2 , p. $77-90$.

Paillet, F. L., 1998, Flow modeling and permeability estimation using borehole flow logs in heterogeneous fractured formations: Water Resources Research, v. 34, no. 5 , p. $997-1010$.

Paillet, F. L., 2000, A field technique for estimating aquifer parameters using flow log data: Ground Water, v. 38, no. 4 , p. 510-521.

Serra, Oberto, 1984, Fundamentals of well-log interpretation: New York, Elsevier, 423 p.

Williams, J.H., and Conger, R.W., 1990, Preliminary delineation of contaminated water-bearing fractures intersected by open-hole bedrock wells: Groundwater Monitoring and Review, v. 10, no. 4, p. 118-126.
Subdistrict Chief

U.S. Geological Survey

2045 Route 112

Coram, NY 11727
U.S. Geological Survey

Branch of Information Services

Box 25286

Denver, CO 80225 